\title{
Determination of $\delta$-aminolaevulinic acid in biological fluids by gas-liquid chromatography with electron-capture detection
}

\author{
Abel GORCHEIN \\ Department of Clinical Pharmacology, St. Mary's Hospital Medical School, Norfolk Place, London W.2, \\ U.K.
}

(Received 11 November 1983/Accepted 17 January 1984)

\begin{abstract}
1. A derivative of $\delta$-aminolaevulinic acid (AmLev), 2-methyl-3-acetyl-4-(3-propionic acid pentafluorobenzyl ester)pyrrole, with favourable properties for g.l.c. with electron-capture detection, was synthesized. Less than $1 \mathrm{pg}$ could be detected on the column. 2. 6-Amino-5-oxohexanoic acid formed the analogous derivative under similar conditions and was used as the internal standard in the development of a highly sensitive and specific assay for AmLev. 3. The method has been applied to peripheral-venous and umbilical-cord plasma and to cerebrospinal fluid of normal and porphyric subjects.
\end{abstract}

$\delta$-Aminolaevulinic acid (AmLev) is the first intermediate in the pathway for haem biosynthesis and is formed by the condensation of glycine with succinyl-CoA in mitochondria. Its levels in human blood plasma are normally very low and presumably result from overflow from the liver and perhaps the bone marrow. In the hereditary hepatic porphyrias (acute intermittent porphyria, variegate porphyria and hereditary coproporphyria), in lead poisoning, and in hereditary tyrosinaemia, however, the plasma levels of AmLev become markedly elevated, with a corresponding increase in its urinary excretion. Severe neurological abnormalities may occur in all these conditions, and the possible role of AmLev in causing neuropathy has been intensively investigated, particularly in relation to the hereditary hepatic porphyrias (for a recent review, see, e.g., Kappas et al., 1983). The clinical relevance of the experimental results obtained, however, remains controversial. A major difficulty has been the lack of methods for the determination of AmLev that are sufficiently sensitive and specific to enable meaningful measurements to be made of changes in its concentration in body fluids, other than urine, or in tissues of normal individuals or even of porphyric subjects. The methods generally used are based on that of Mauzerall \& Granick (1956) and depend on spectrophotometric measurement of the chromo-

Abbreviations used: AmLev, $\delta$-aminolaevulinic acid; g.c.-m.s., gas chromatography-mass spectrometry; AmLev-pyrrole, 2-methyl-3-acetyl-4-(3-propionic acid)pyrrole; $\mathrm{C}_{6}$-pyrrole, 2-methyl-3-acetyl-4-(4-butyric acid)pyrrole. phore obtained by allowing the pyrrole produced by a Knorr-type condensation of AmLev with acetylacetone or ethyl acetoacetate to react with Ehrlich's $p$-dimethylaminobenzaldehyde reagent. The lack of specificity due to the presence of other aminoketones, such as aminoacetone, can be overcome by separation of the derived pyrroles on ionexchange resin (e.g. Marver et al., 1966), but the sensitivity of these methods is limited to the microgram range. Later developments have included g.l.c. with detection by flame ionization of the trimethylsilyl (Gibbs et al., 1974) or methyl derivatives (MacGee et al., 1977) of the Knorr pyrroles. The former method was not sensitive enough to measure AmLev in normal plasma, and although the latter represents a significant increase in sensitivity into the nanogram range, $3 \mathrm{ml}$ of plasma were required for a single analysis, and levels of AmLev in some normal plasmas still appeared to be near the lower limit of detection.

The present work describes the synthesis of a derivative of AmLev with properties suitable for g.l.c. with electron-capture detection, and its application to the development of a highly sensitive and specific method for the measurement of AmLev in picogram amounts in plasma and other biological fluids or tissues.

\section{Materials and methods}

\section{Chemicals}

AmLev hydrochloride and Dowex (50W, X8, 200-400 mesh) cation-exchange resin were obtained from Sigma (London) Chemical Co., Poole, 
Dorset, U.K. Glutaryl chloride methyl ester, hippuric acid, 4-picoline and $N N$-di-isopropylethylamine were purchased from Aldrich Chemical Co., Gillingham, Dorset, U.K. Acetylacetone was from BDH, Poole, Dorset, U.K., and was redistilled. $\alpha$-Bromo-2,3,4,5,6-pentafluorotoluene (pentafluorobenzyl bromide) was from Pierce and Warriner, Chester, U.K. Working dilutions were made in acetonitrile and stored at $-18^{\circ} \mathrm{C}$. Acetonitrile was obtained from Fisons, Loughborough, Leics., U.K., or Rathburn Chemicals, Walkerburn, Peeblesshire, Scotland, U.K., and was fractionally distilled, the middle fraction with b.p. $81.6^{\circ} \mathrm{C}$ being collected and stored at $-18^{\circ} \mathrm{C}$. Diethyl ether (AR grade; BDH) was extracted three times with aq. $\mathrm{NH}_{3}$ [sp.gr. $0.88 ; 1: 10(\mathrm{v} / \mathrm{v})$ dilution with water] and washed three times with distilled water before use. Porphobilinogen was obtained from the urine of porphyric patients as described by Cookson \& Rimington (1954). Other chemicals were purchased from commercial sources and were of the highest grade available or were synthesized as described below.

\section{T.l.c.}

This was done on plastic sheets coated with silica gel (Merck 5748, BDH) which were prewashed twice by ascending development with acetone and then allowed to dry at $22^{\circ} \mathrm{C}$. Samples were spotted at the origin with Carlsberg pipettes, dried with a $\mathrm{N}_{2}$ stream and run in prescored lanes $1.5-2 \mathrm{~cm}$ wide with benzene/acetone $(4: 1, \mathrm{v} / \mathrm{v})$ as solvent. Authentic compounds used as markers were located by spraying with Ehrlich's reagent, $p$ dimethylaminobenzaldehyde $(2 \%, w / v$, in $6 \mathrm{M}-$ $\mathrm{HCl})$, after cutting the appropriate lanes from the sheet. The sample zones were then excised and eluted with $1 \mathrm{ml}$ of acetone.

\section{G.l.c.}

This was done on a Becker-Packard 417 gas chromatograph fitted with a $75 \mathrm{mCi}-{ }^{-3} \mathrm{H}$ (scandium foil) electron-capture detector, and subsequently on a Pye-Unicam PU 4500 gas chromatograph fitted with a $10 \mathrm{mCi}-{ }^{63} \mathrm{Ni}$ detector. Glass columns, $1.5 \mathrm{~m}$ (or $2 \mathrm{~m}) \times 3 \mathrm{~mm}$ internal diameter, packed with $3 \%$ OV 17 on Chromosorb WHP (80-100 or 100-120 mesh) were used. The oven was operated isothermally at $250^{\circ} \mathrm{C}$ and the temperature of the injection port was $260^{\circ} \mathrm{C}$ and that of the detector $265^{\circ} \mathrm{C}$. The carrier gas was $\mathrm{N}_{2}$ at $30 \mathrm{ml} / \mathrm{min}$.

\section{Mass spectrometry and g.c.-m.s.}

These were done on a VG Micromass MM 12030 mass spectrometer in series with a Pye 204 gas chromatograph. A $15 \mathrm{~m}$ fused-silica capillary column coated with SE-54 was used for the g.c., with a temperature program from 200 to $250^{\circ} \mathrm{C}$ at $8^{\circ} / \mathrm{min}$. For m.s. the filament emission was $200 \mu \mathrm{A}$, the ionization energy $70 \mathrm{eV}$ and the source temperature $200^{\circ} \mathrm{C}$.

\section{I.r. spectroscopy}

This was done on a Perkin-Elmer $157 \mathrm{G}$ spectrometer as a Nujol mull.

\section{N.m.r. spectroscopy}

${ }^{1} \mathrm{H}$ and ${ }^{19} \mathrm{~F}$ n.m.r. spectra were obtained on a Brucker 250 spectrometer at 250 and $238 \mathrm{MHz}$ respectively.

\section{Microanalysis}

This was done by Butterworth Laboratories Ltd., Teddington, Middx., U.K.

\section{Preparation of compounds}

AmLev-pyrrole. This was synthesized as described by Mauzerall \& Granick (1956) and recrystallized by dissolving the compound in a minimal volume of methanol and adding water until the crystals appeared.

2-Methyl-3-acetyl-4-(3-propionic acid pentafluorobenzyl ester)pyrrole. This was synthesized by allowing a suspension of AmLev-pyrrole $(143 \mu \mathrm{mol}$ in $0.5 \mathrm{ml}$ of acetonitrile) to react with pentafluorobenzyl bromide $(1 \mathrm{mmol})$ and $N N$-di-isopropylethylamine $(718 \mu \mathrm{mol})$ at $25^{\circ} \mathrm{C}$ for $20 \mathrm{~min}$. The product was recrystallized from acetonitrile in approx. $90 \%$ yield. On t.l.c., a single spot, $R_{F} 0.43$, giving a purple colour in the cold with Ehrlich's reagent, was obtained. The m.p. was $143-144^{\circ} \mathrm{C}$.

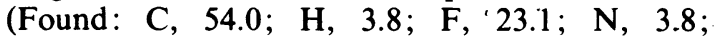
$\mathrm{C}_{17} \mathrm{H}_{14} \mathrm{O}_{3} \mathrm{NF}_{5}$ requires $\mathrm{C}, 54.4 ; \mathrm{H} ; 3.7 ; \mathrm{F}, 25.3$; $\mathrm{N}, 3.7 \%$.) Mass spectrum (direct inlet and g.c.m.s.) gave prominent peaks at $m / e 375\left(M^{+}\right)$, $332\left(M^{+}-\mathrm{CH}_{3} \mathrm{CO}\right), 194\left(M^{+}-\mathrm{C}_{7} \mathrm{H}_{2} \mathrm{~F}_{5}\right), \cdot 181$ $\left(\mathrm{C}_{7} \mathrm{H}_{2} \mathrm{~F}_{5}\right)$ and $136\left[M^{+}-\left(\mathrm{C}_{7} \mathrm{H}_{2} \mathrm{~F}_{5}+\mathrm{CH}_{2} \mathrm{CO}_{2}\right)\right]$.

The i.r. spectrum had prominent absorption bands at $1730 \mathrm{~cm}^{-1}(\mathrm{C}=\mathrm{O}$ stretch $)$ and 1185 $[\mathrm{C}-\mathrm{C}(=\mathrm{O})-\mathrm{O}$ stretch], indicative of an ester carbonyl, and a broad band at 3220 (NH stretch).

${ }^{1} \mathrm{H}$ n.m.r. spectrum (reference compound tetramethylsilane) showed $\delta$ (p.p.m.) [ $\left({ }^{2} \mathrm{H}\right)$ acetonitrile] $9.1(\mathrm{H}$, broad s, NH), $6.3(\mathrm{H}, \mathrm{s}, \mathrm{NCH}), 5.16(2 \mathrm{H}, \mathrm{s}$, $\left.\mathrm{COCH}_{2}\right), 2.88\left(2 \mathrm{H}, \mathrm{t}, \mathrm{CH}_{2} \mathrm{CH}_{2} \mathrm{CO}\right), 2.55(2 \mathrm{H}, \mathrm{t}$, $\left.\mathrm{CH}_{2} \mathrm{CH}_{2} \mathrm{CO}\right), 2.43\left(3 \mathrm{H}, \mathrm{s}, \mathrm{CH}_{3} \mathrm{CO}\right)$ and $2.32(3 \mathrm{H}$, s, $\mathrm{NCC}_{3}$ ).

${ }^{19} \mathrm{~F}$ n.m.r. spectrum (reference compound trichlorofluoromethane) gave $\delta$ (p.p.m.) $\left[\left({ }^{2} \mathrm{H}\right)\right.$ acetonitrile] $-142.55(2 \mathrm{~F}$, quad, $o-\mathrm{F}),-154.28(\mathrm{~F}, \mathrm{t}$, $p-\mathrm{F}),-163.04(2 \mathrm{~F}$, sext, $m-\mathrm{F})$.

From elemental analysis and mass spectrum, the compound contained only one pentafluorobenzyl group. This was shown by i.r. and n.m.r. spectroscopy to be in ester linkage with the propionic acid side chain, leaving the pyrrole NH unsubstituted. 
The slightly low analysis for fluorine is attributed to difficulties in the standardization of the ionchromatography method.

6-Amino-5-oxohexanoic acid (Gibson et al., 1955). This was synthesized by the adaptation (MacGee et al., 1977) of the method of Aranowa et al. (1973) for the synthesis of AmLev. The yield and purity were markedly improved by allowing commercially available glutaryl chloride methyl ester to react with the hippuric acid, and maintaining the temperature below $35^{\circ} \mathrm{C}$ during the removal under reduced pressure of the aqueous $\mathrm{HCl}$ used for hydrolysis. The m.p. of the white crystalline first product obtained was $141^{\circ} \mathrm{C}$, and after a single recrystallization, by solution in minimal conc. $\mathrm{HCl}$ and addition of acetone, it was $146^{\circ} \mathrm{C}$ [literature values: $149-150^{\circ} \mathrm{C}$ (Gibson et al., 1955) and 128 $131^{\circ} \mathrm{C}$ (MacGee et al., 1977)].

2-Methyl-3-acetyl-4-(4-butyric acid)pyrrole $\left(C_{6}\right.$ pyrrole). This was synthesized in the same way as the corresponding derivative of AmLev (see above). The m.p. was $190^{\circ} \mathrm{C}$.

2-Methyl-3-acetyl-4-(4-butyric acid pentafluorobenzyl ester)pyrrole. $\mathrm{C}_{6}$-pyrrole, $136 \mu \mathrm{mol}$ in $0.5 \mathrm{ml}$ of acetonitrile, was allowed to react with $1 \mathrm{mmol}$ of pentafluorobenzyl bromide and $718 \mu \mathrm{mol}$ of $N N$ di-isopropylethylamine in a Teflon-stoppered vial at $25^{\circ} \mathrm{C}$ for $20 \mathrm{~min}$. The yield after recrystallization from acetonitrile was more than $90 \%$. On t.l.c. there was a single spot, $R_{F} 0.45$, giving a purple colour with Ehrlich's reagent. The m.p. was $120^{\circ} \mathrm{C}$. (Found: C, 55.6; H, 4.1; F, 22.4; N, 3.7; $\mathrm{C}_{18} \mathrm{H}_{16} \mathrm{O}_{3} \mathrm{NF}_{5}$ requires: $\mathrm{C}, 55.5 ; \mathrm{H}, 4.1 ; \mathrm{F}, 24.4$; $\mathrm{N}, 3.6 \%$.)

The structure of both these pyrrole derivatives from 6-amino-5-oxohexanoic acid was confirmed by $m$.s. and g.c. - m.s. Their fragmentation patterns were analogous to those of the corresponding derivatives from AmLev. Thus $\mathrm{C}_{6}$-pyrrole had mass spectrum (direct inlet): $\mathrm{m} / \mathrm{e} 209\left(M^{+}, 65 \%\right)$, $166\left(M^{+}-\mathrm{CH}_{3} \mathrm{CO}, 45 \%\right), 150\left(M^{+}-\mathrm{CH}_{2} \mathrm{CO}_{2} \mathrm{H}\right.$, $100 \%$, base peak), $136\left(M^{+}-\mathrm{CH}_{2} \mathrm{CH}_{2} \mathrm{CO}_{2} \mathrm{H}\right.$, $90 \%$ ), compared with AmLev-pyrrole m/e 195 $\left(M^{+}, 45 \%\right), \quad 152\left(M^{+}-\mathrm{CH}_{3} \mathrm{CO}, \quad 30 \%\right), 136$ $\left(M^{+}-\mathrm{CH}_{2} \mathrm{CO}_{2} \mathrm{H}, \quad 30 \%\right), \quad 122\left(M^{+}-\mathrm{CH}_{2} \mathrm{CH}_{2}^{-}\right.$ $\mathrm{CO}_{2} \mathrm{H}, 100 \%$, base peak).

The pentafluorobenzyl derivative showed peaks at $\mathrm{m} / \mathrm{e} 389\left(\mathrm{M}^{+}, 20 \%\right), 346\left(\mathrm{M}^{+}-\mathrm{CH}_{3} \mathrm{CO}, 28 \%\right)$, $208\left(M^{+}-\mathrm{C}_{7} \mathrm{H}_{2} \mathrm{~F}_{5}, 8 \%\right), 181\left(\mathrm{C}_{7} \mathrm{H}_{2} \mathrm{~F}_{5}, 50 \%\right), 150$ $\left[M^{+}-\left(\mathrm{C}_{7} \mathrm{H}_{2} \mathrm{~F}_{5}+\mathrm{CH}_{2} \mathrm{CO}_{2}\right), \quad 100 \%\right.$, base peak) and $136\left[M^{+}-\left(\mathrm{C}_{7} \mathrm{H}_{2} \mathrm{~F}_{5}+\mathrm{CH}_{2} \mathrm{CH}_{2} \mathrm{CO}_{2}\right), 62 \%\right]$.

The assignment of the pentafluorobenzyl group to the ester linkage, as with the AmLev derivative, was confirmed by i.r. and n.m.r. spectroscopy: the i.r. spectrum included strong absorption bands at 1730,1180 and $3210 \mathrm{~cm}^{-1}$ similar to those of the AmLev derivative. ${ }^{1} \mathrm{H}$ n.m.r. spectrum with tetramethylsilane as reference compound showed $\delta$ (p.p.m.) [( $\left.{ }^{2} \mathrm{H}\right)$ acetonitrile] $9.1(\mathrm{H}$, broad s, NH), $6.35(\mathrm{H}, \mathrm{s}, \mathrm{NCH}), 5,17\left(2 \mathrm{H}, \mathrm{s}, \mathrm{COCH}_{2}\right), 2.62(2 \mathrm{H}$, t, $\left.\mathrm{CH}_{2} \mathrm{CH}_{2} \mathrm{CH}_{2} \mathrm{CO}\right), 2.43\left(3 \mathrm{H}, \mathrm{s}, \mathrm{CH}_{3} \mathrm{CO}\right), 2.31$ $\left(5 \mathrm{H}, \mathrm{t}\right.$, overlapping $\mathrm{s}, \mathrm{CH}_{2} \mathrm{CH}_{2} \mathrm{CH}_{2} \mathrm{CO}$ and $\left.\mathrm{NCCH}_{3}\right), 1.78\left(2 \mathrm{H}, \mathrm{t}, \mathrm{CH}_{2} \mathrm{CH}_{2} \mathrm{CH}_{2} \mathrm{CO}\right) .{ }^{19} \mathrm{~F}$ n.m.r. spectrum with trichlorofluoromethane as reference compound had $\delta$ (p.p.m.) $\left[\left({ }^{2} \mathrm{H}\right)\right.$ acetonitrile] $-142.59(2 \mathrm{~F}$, quad, $o-\mathrm{F}),-154.38(\mathrm{~F}, \mathrm{t}$, $p-\mathrm{F}),-163.05(2 \mathrm{~F}$, sext, $m-\mathrm{F})$.

\section{Biological methods}

Samples and human subjects. Samples of blood were obtained from normal subjects with their informed consent. Blood and other biological fluids from patients were surplus to the requirements for essential clinical investigations.

Hydroxymethylbilane synthase (EC 4.3.1.8; formerly uroporphyrinogen I synthase). This was determined by the method of Strand et al. (1970).

\section{Determination of AmLev in plasma}

Plasma samples and standards. Blood was collected in plastic tubes containing EDTA and was immediately centrifuged. The separated plasma was kept at $-18^{\circ} \mathrm{C}$ or $-70^{\circ} \mathrm{C}$ until assayed. No significant loss of AmLev was found in samples kept at $-70^{\circ} \mathrm{C}$ for up to 6 months compared with samples assayed within $24 \mathrm{~h}$. By contrast, aqueous solutions of AmLev hydrochloride $(1 \mu \mathrm{g} / \mathrm{ml})$ lost up to $50 \%$ of their assayable AmLev after 6 weeks and were therefore prepared from the solid at weekly intervals for use as calibration standards. Dilute solutions of 6-amino-5-oxohexanoic acid $(1 \mu \mathrm{g} / \mathrm{ml})$ used as the internal standard were stable for at least 4 weeks at $-18^{\circ} \mathrm{C}$. Moderate losses would not affect the results of the assay, but would give a steeper slope of the calibration line.

Deproteinization of plasma and preparation of pyrrole derivatives of AmLev and internal standard. To $0.05-1.0 \mathrm{ml}$ portions of plasma made up to $1.0 \mathrm{ml}$ with $0.9 \% \mathrm{NaCl}$ solution, where required, were added $150 \mathrm{ng}(826 \mathrm{pmol})$ of 6-amino-5-oxohexanoic acid hydrochloride as internal standard. The samples were then diluted to $3.0 \mathrm{ml}$ with ionfree water and were loaded on to $6 \mathrm{~mm} \times 18 \mathrm{~mm}$ columns of Dowex ( $50 \mathrm{~W}, \mathrm{H}^{+}$form) resin. After the liquid had passed.through, the columns were washed free of residual protein with $2 \times 5 \mathrm{ml}$ portions of ion-free water. Fibrin, which occasionally formed and remained at the top of the column when larger volumes of plasma $(0.5-1.0 \mathrm{ml})$ were used, was broken up with Pasteur pipettes to allow the flow to proceed. The AmLev and internal standard were then eluted with $4.0 \mathrm{ml}$ of $1 \mathrm{M}$ $\mathrm{NaH}_{2} \mathrm{PO}_{4}$, previously adjusted to $\mathrm{pH} 7.0$ with $10 \mathrm{M}$ $\mathrm{NaOH}$, into screw-cap vials. After addition of $0.10 \mathrm{ml}$ of a $1: 1(\mathrm{v} / \mathrm{v})$ aqueous dilution of $\mathrm{H}_{3} \mathrm{PO}_{4}$ (sp.gr. 1.75) and $0.05 \mathrm{ml}$ of acetylacetone, the vials 
were loosely stoppered and heated for $10 \mathrm{~min}$ in a boiling-water bath. The reaction mixtures were allowed to cool and shaken twice with $3 \mathrm{ml}$ portions of hexane and the extracts were discarded. Any emulsions forming at this stage were broken by freezing in an acetone/solid- $\mathrm{CO}_{2}$ bath, followed by thawing at room temperature; alternatively the hexane was poured off the frozen aqueous phase. The $\mathrm{pH}$ was then lowered to 2.0 by addition of $260 \mu \mathrm{l}$ of conc. $\mathrm{HCl}$ and the pyrroles were extracted with $2 \mathrm{ml}, 2 \mathrm{ml}$ and $1 \mathrm{ml}$ portions of diethyl ether. The pooled ether extracts were dried by shaking with anhydrous $\mathrm{Na}_{2} \mathrm{SO}_{4}$, transferred to tapered glass vials, and the pyrroles were back-extracted with three $0.1 \mathrm{ml}$ portions of aq. $\mathrm{NH}_{3}$ [sp.gr. 0.88 , diluted $1: 10(\mathrm{v} / \mathrm{v})$ with distilled water]. The pooled extracts were dried under reduced pressure in a desiccator over $\mathrm{H}_{2} \mathrm{SO}_{4}$.

Alternatively, the plasma samples, made up to $1.0 \mathrm{ml}$ with $0.9 \% \mathrm{NaCl}$ solution where necessary and containing the internal standard, were deproteinized by the addition of $0.33 \mathrm{ml}$ of aq. $20 \%$ $(w / v)$ trichloroacetic acid. The clear supernatants obtained after centrifuging at $10000 \mathrm{~g}$ for $10 \mathrm{~min}$ were transferred to $7 \mathrm{ml}$ glass vials fitted with Teflon-lined screw caps. The pellets were triturated with $1.0 \mathrm{ml}$ of $5 \%(\mathrm{w} / \mathrm{v})$ trichloroacetic acid and the suspensions were re-centrifuged as previously. The combined supernatants from each sample were extracted twice with $5 \mathrm{ml}$ portions of diethyl ether to remove the trichloroacetic acid, and, after addition of $0.05 \mathrm{ml}$ of acetylacetone and $0.3 \mathrm{ml}$ of $1 \mathrm{M}-\mathrm{NaH}_{2} \mathrm{PO}_{4}$, the vials were loosely stoppered and heated in a boiling-water bath for $10 \mathrm{~min}$. After cooling, the reaction mixtures were shaken twice with $3 \mathrm{ml}$ portions of hexane, which were discarded. The $\mathrm{pH}$ was then lowered to 2.0 by addition of $10 \mu \mathrm{l}$ of conc. $\mathrm{HCl}$ and the pyrroles were extracted and further processed as described above.

Conversion of pyrroles into pentafluorobenzyl derivatives and purification by t.l.c. To the residues in $0.3 \mathrm{ml}$ tapered glass vials were successively added $11 \mu \mathrm{mol}$ of pentafluorobenzyl bromide and $5 \mu \mathrm{mol}$ of $N N$-di-isopropylethylamine, each in $10 \mu \mathrm{l}$ of acetonitrile. The vials were closed with Teflonlined screw caps, heated at $50^{\circ} \mathrm{C}$ for $5 \mathrm{~min}$, or kept at room temperature $\left(22-25^{\circ} \mathrm{C}\right)$ for $15 \mathrm{~min}$, and the solvent and excess reagents were removed by a $\mathrm{N}_{2}$ stream in a fume hood. The residues were dissolved in $0.05 \mathrm{ml}$ of acetone and the pentafluorobenzyl derivatives were purified by t.l.c. as described above and eluted with $1 \mathrm{ml}$ of acetone.

Electron-capture g.l.c. Portions $(1 \mu \mathrm{l})$ of the eluate were injected directly or after concentration. Under the conditions described above, typical retention times for the AmLev derivative and the internal standard were $6 \mathrm{~min} 40 \mathrm{~s}$ and $10 \mathrm{~min} 8 \mathrm{~s}$
$\mathrm{NH}_{2} \mathrm{CH}_{2} \mathrm{COCH}_{2} \mathrm{CH}_{2} \mathrm{CO}_{2} \mathrm{H}$

I<smiles>CC(=O)c1cc[nH]c1CCC(=O)O</smiles>

III<smiles>COC(=O)CCc1ccc(F)c(F)c1</smiles>

$\mathrm{V}$
$\mathrm{NH}_{2} \mathrm{CH}_{2} \mathrm{COCH}_{2} \mathrm{CH}_{2} \mathrm{CH}_{2} \mathrm{CO}_{2} \mathrm{H}$

II<smiles>CC(=O)c1cc[nH]c1CCCC(=O)O</smiles>

IV<smiles>COC(=O)CCCCCc1ccc(F)c(F)c1</smiles>

VI

Scheme 1. Synthesis of pentafluorobenzyl esters of AmLev and 6-amino-5-oxohexanoic acid pyrroles I, AmLev; II, 6-amino-5-oxohexanoic acid; III, AmLev-pyrrole; IV, $\mathrm{C}_{6}$-pyrrole; V, 2-methyl-3-acetyl-4-(3propionic acid pentafluorobenzyl ester)pyrrole; VI, 2-methyl-3-acetyl-4-(4-butyric acid pentafluorobenzyl ester)pyrrole. Details of the individual reactions are described in the Materials and methods section. 
respectively. Quantification was on the basis of the ratio of the peak height of the pentafluorobenzyl derivative of AmLev-pyrrole to that of the internal standard.

\section{Results and discussion}

The synthesis of the pentafluorobenzyl esters of the Knorr pyrroles from AmLev and 6-amino-5oxohexanoic acid is shown in Scheme 1. The structures were established as described in the Materials and methods section.

The reaction conditions used for the assay were the most favourable for the near-quantitative synthesis of the esters from submicrogram amounts of the pyrroles, on the basis of a systematic examination of various reagents, concentrations and reaction times. The advantages of $N N$-di-isopropylethylamine as an acceptor of $\mathrm{HBr}$ in reactions with pentafluorobenzyl bromide, compared with previously described methods (Kawahara, 1968; Ehrsson, 1971), were first described in relation to prostaglandins (Wickramasinghe et al., 1973). The present work extends the observations to aminoketone-derived pyrrole carboxylic acids. Unlike the findings with prostaglandin-containing extracts, however, neither removal of excess reagents with a stream of $\mathrm{N}_{2}$ after the reaction, nor even purification of the pyrroles by t.l.c. before esterification, reduced the background sufficiently for g.l.c.-electron-capture detection. It was essential therefore to finally 'clean up' the esters. The t.l.c. conditions chosen did not fully separate the derivatives $\left(R_{F}=0.43\right.$ and 0.45 for the esters of AmLev- and 6-amino-5-oxohexanoic acid-pyrrole respectively) so that the internal standard may with advantage act as a carrier at this stage for the AmLev compound. Complete resolution was, however, obtained by g.l.c. (Fig. 1). The peaks were symmetrical, despite the presence of the free NH group. Further derivatization to the $N$-trimethylsilyl compounds was demonstrated by reaction of the t.l.c. eluates with NO-bis(trimethylsilyl)acetamide. Only slight reductions in the retention times of the derivatives were obtained, however, which did not appear to justify the additional procedures.

When different amounts of AmLev and a fixed amount of 6-amino-5-oxohexanoic acid were added to portions of the same plasma, which were then taken through the assay procedure, a linear relationship was obtained between the ratios of the peak heights of their pentafluorobenzyl esters and the amount of AmLev added, consistent with the internal standard having similar extraction and derivatizing properties to those of AmLev (Fig. 2). The intercept on the abscissa is a measure of the AmLev content of the plasma sample. The pro-

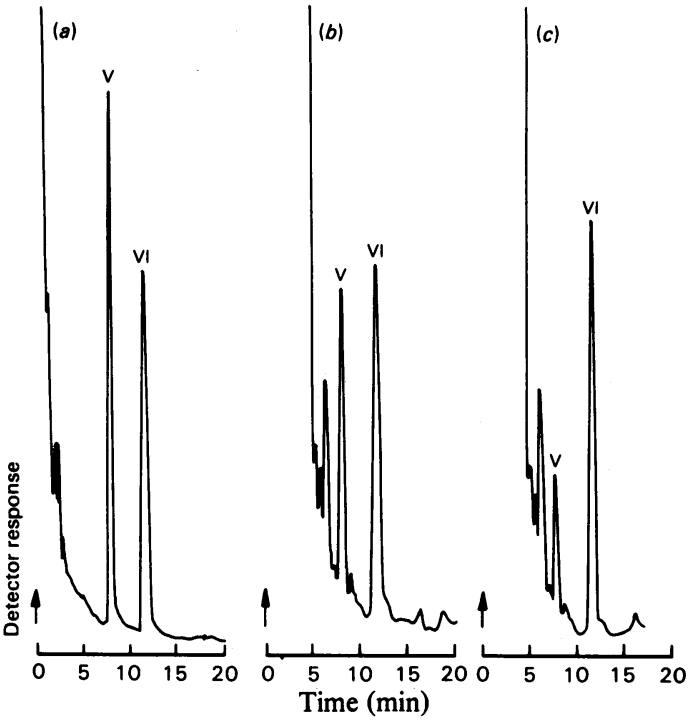

Fig. 1. G.l.c. of pentafluorobenzyl esters of pyrrole carboxylic acids

(a) Approx. 30pg (in acetone) of the derivatives from $\delta$-aminolaevulinic acid (V, Scheme 1) and 6amino-5-oxohexanoic acid (VI) were injected on to the column. The amplifier attenuation was $\times 32$. (b) and (c) are chromatographs from assays of plasma from a porphyria patient $(0.1 \mathrm{ml})$ and from a normal subject $(1.0 \mathrm{ml})$ respectively. A $1 \mu$ l portion from the t.l.c. eluates $(1 \mathrm{ml})$ was injected (attenuation $\times 8$ ). The AmLev contents were calculated to be $(b)$ $750 \mathrm{ng} / \mathrm{ml}$ and $(c) 29 \mathrm{ng} / \mathrm{ml}$. The arrows indicate the point of injection. Details are given in the Materials and methods section.

cedure was repeated after preincubating the plasma with AmLev dehydratase (partially purified from Rhodopseudomonas spheroides; Gibson et al., 1955), and a parallel line through the origin was obtained, consistent with the specificity of the method for AmLev. When AmLev and internal standard were added to $0.9 \% \mathrm{NaCl}$ solution, similar results were obtained, providing the basis for a highly sensitive and specific assay for AmLev. The maximum linear response originally obtained was to approx. $100 \mathrm{pg}$ of the derivatives 'on the column' and was limited by the small linear dynamic range of the $75 \mathrm{mCi}^{-3} \mathrm{H}$ (scandium foil) electron-capture detector available. The subsequent use of a Pye-Unicam $10 \mathrm{mCi}-63 \mathrm{Ni}$ detector and PU 4500 chromatograph allowed an extended linear range of response to about $800 \mathrm{pg}$, with greater sensitivity, giving a detection limit of approx. $0.3 \mathrm{pg}$ 'on the column'.

The apparent recovery of AmLev added to plasma or to $0.9 \% \mathrm{NaCl}$ solution, as determined from standard curves, was $100 \pm 5 \%$. The absolute 


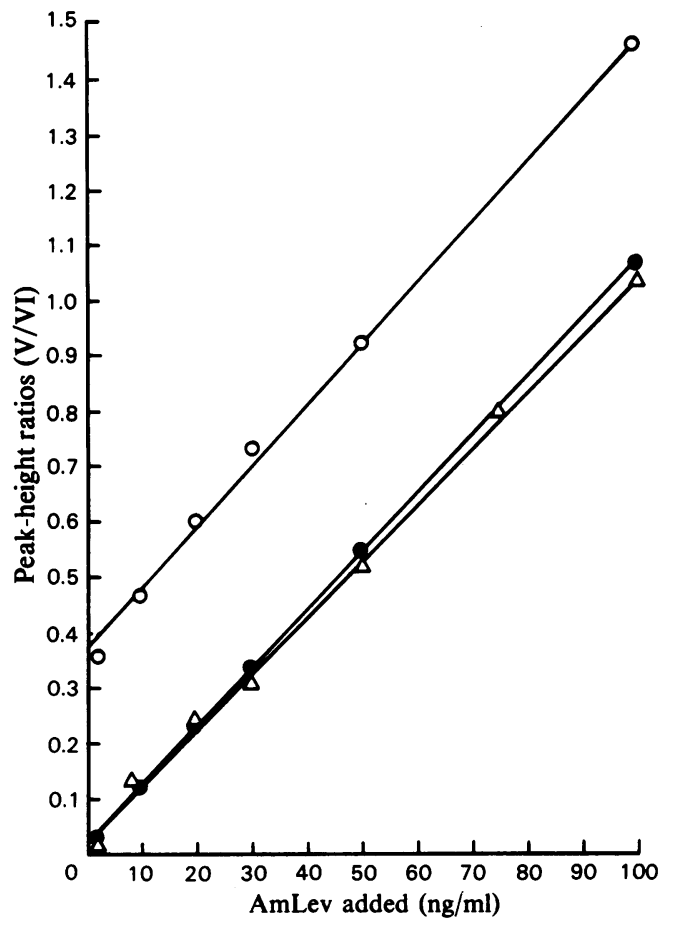

Fig. 2. Standard curves for recovery of $\delta$-aminolaevulinic acid added to human plasma and to $0.9 \% \mathrm{NaCl}$ solution

Peak-height ratios of the pentafluorobenzyl derivatives of AmLev-pyrrole (V, Scheme 1) and 6-amino5-oxohexanoic acid pyrrole (VI) used as internal standards: $O$, AmLev and internal standard added to $1 \mathrm{ml}$ portions of plasma; 0 , plasma incubated with AmLev-dehydrase for $70 \mathrm{~min}$ at $37^{\circ} \mathrm{C}$ and then placed in an ice bath at $0^{\circ} \mathrm{C}$. AmLev and internal standard were added to $1 \mathrm{ml}$ portions of plasma, immediately followed by the addition of $0.33 \mathrm{ml}$ of $20 \%(w / v)$ trichloroacetic acid; $\triangle$, AmLev and internal standard added to $1 \mathrm{ml}$ of $0.9 \% \mathrm{NaCl}$ solution. Portions $(1 \mu \mathrm{l})$ of the t.l.c. eluate (total volume $1 \mathrm{ml}$ ) were injected. At the lower end of the range, improved signal-to-noise ratios were obtained by concentrating portions of the t.l.c. eluate 5-10-fold before injection. The absolute amounts of the derivatives injected on to the column in this experiment with the ${ }^{3} \mathrm{H}$ (scandium foil) detector were $3-50 \mathrm{pg}$, calculated as AmLev hydrochloride. The AmLev content of the plasma was $33 \mathrm{ng} / \mathrm{ml}$. The blood was collected in plastic tubes containing lithium heparin to avoid inhibition of AmLev dehydrase by EDTA.

total recovery, however, from experiments with 4$\left[{ }^{14} \mathrm{C}\right]$ AmLev and by calibration of the g.l.c. response with pure pentafluorobenzyl esters, was only $10-15 \%$. Losses were at a number of steps, but were similar whether plasma or $0.9 \% \mathrm{NaCl}$ solution had been used. Despite this low absolute

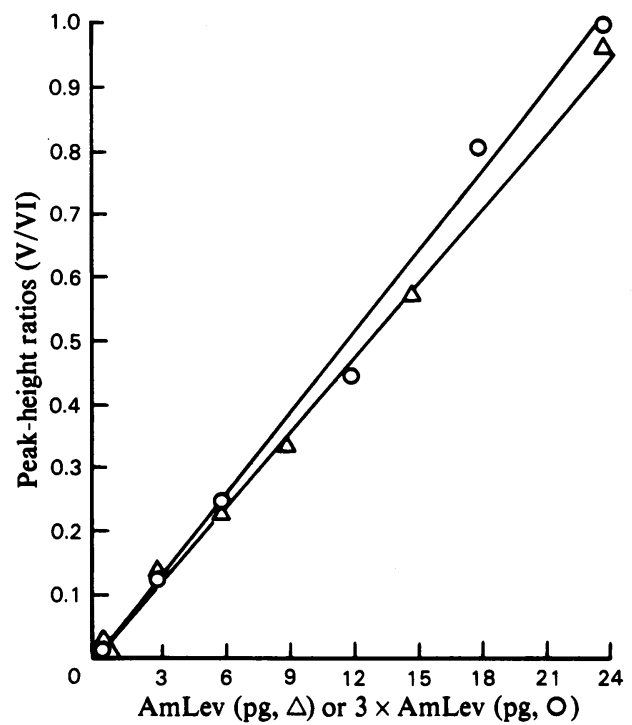

Fig. 3. Apparent and absolute recoveries of AmLev added to $0.9 \% \mathrm{NaCl}$ solution

Peak-height ratios (V/VI) (see the legend to Fig. 2) were determined: $O$, after addition of AmLev to give concentrations of $0-80 \mathrm{ng} / \mathrm{ml}$, and of internal standard to $0.9 \% \mathrm{NaCl}$ solution, followed by the whole assay procedure described in the text, and $\Delta$, in mixtures of pentafluorobenzyl derivatives directly injected on the column. The amounts of pentafluorobenzyl esters injected on the column were $0-24 \mathrm{pg}(\mathrm{V})$ and $45 \mathrm{pg}$ (VI), calculated as AmLev hydrochloride and 6-amino-5-oxohexanoic acid hydrochloride respectively, and for the samples taken through the assay, $0-8 \mathrm{pg}$ (V) and $15 \mathrm{pg}$ (VI) $\left({ }^{63} \mathrm{Ni}\right.$ detector).

recovery of AmLev, its losses and those of the internal standard were proportional and reproducible. Thus different amounts of pure pentafluorobenzyl derivative from AmLev and a constant amount of the corresponding compound from 6amino-5-oxohexanoic acid were chromatographed and a plot of their peak-height ratios against the amount of AmLev was compared with that of the products obtained by first adding AmLev and the internal standard to $0.9 \% \mathrm{NaCl}$ solution and then carrying out the entire assay procedure: the two curves (Fig. 3) were similar.

Plasma values for AmLev in four normal individuals, each sample being determined four times, were $28( \pm 1.2), 52( \pm 2.7), 11( \pm 0.80)$ and 31 $( \pm 1.4) \mathrm{ng} / \mathrm{ml}$. Assay of AmLev in umbilical-cord and peripheral-venous plasma at spontaneous natural delivery of a patient with acute intermittent porphyria gave values of $730 \mathrm{ng} / \mathrm{ml}$ and $1100 \mathrm{ng} / \mathrm{ml}$ respectively, whereas the mean value of AmLev in six cord plasmas from non-porphyric 
subjects was $18.5 \mathrm{ng} / \mathrm{ml}$ (range $16-24 \mathrm{ng} / \mathrm{ml}$ ). Since its cord erythrocyte hydroxymethylbilane synthase activity was normal $(79 \mathrm{nmol}$ of uroporphyrinogen $\mathrm{I} / \mathrm{h}$ per $\mathrm{ml}$ of red blood cells; the mean for 11 normal cord blood samples was 60 , with a range of 45-80; cf. Kreimer-Birnbaum \& Bannerman, 1975), the newborn was not a carrier of the gene for acute intermittent porphyria, and it was concluded that its raised level of AmLev was due to passage from the maternal circulation. Assays of six samples of cerebrospinal fluid from patients without porphyria gave a mean value for AmLev of $3.8 \mathrm{ng} / \mathrm{ml}$ (range $<1 \mathrm{ng} / \mathrm{ml}-8 \mathrm{ng} / \mathrm{ml}$ ). A single sample from a patient with acute intermittent porphyria, suspected of having meningitis, was $32 \mathrm{ng} / \mathrm{ml}$ at a time when the plasma value was $300 \mathrm{ng} / \mathrm{ml}$.

These results, in a small number of samples, all obtained by the method described here, are consistent with some data scattered in the literature and obtained by a variety of methods. Although the assay procedure is lengthy, the derivatives were stable in the t.l.c. eluate for at least 6 months at $-18^{\circ} \mathrm{C}$. A batch size of 20 including a five- or six-point standard curve was found convenient. Further work is required to provide definitive information on AmLev levels under a variety of physiological and pathological conditions.

I am grateful to Dr. P. Brooks (V.G. Organic Ltd., Altrincham, Cheshire, U.K.) for the mass spectra, and thank Mrs. J. Elliot and Miss F. B. Mills (Department of Chemistry, King's Collage, University of London) for running the n.m.r. spectra. I also thank the Department of Chemical Pathology, St. Mary's Hospital, London W.2., U.K., for samples of cerebrospinal fluid, and the Department of Obstetrics, St. Mary's Hospital, London W.9., U.K., for umbilical-cord blood.

\section{References}

Aranowa, N. I. S., Machowa, N. W., Sawjalow, S. I., Wolkenstein, J. B. \& Kunizkaja, G. M. (1973) Fed. Rep. Ger. Patent 2208800

Cookson, G. H. \& Rimington, C. (1954) Biochem. J. 57, 476-484

Ehrsson, H. (1971) Acta Pharm. Suec. 8, 113-118

Gibbs, B. F., Itiaba, K. \& Crawhall, J. C. (1974) Biochem. Med. 11, 165-170

Gibson, K. D., Neuberger, A. \& Scott, J. J. (1955) Biochem. J. 61, 618-629

Kappas, A., Sassa, S. \& Anderson, K. E. (1983) in The Metabolic Basis of Inherited Disease, 5th edn. (Stanbury, J. B., Wyngaarden, J. B., Frederickson, D. S., Goldstein, J. L. \& Brown, M. S., eds.), pp. 1301-1384, McGraw-Hill, New York

Kawahara, F. K. (1968) Anal. Chem. 40, 2073-2075

Kreimer-Birnbaum, M. \& Bannerman, R. M. (1975) Arch. Dis. Child. 50, 494-495

MacGee, J., Roda, S. M. B., Elias, S. V., Lington, A., Tabor, M. W. \& Hammond, P. B. (1977) Biochem. Med. 17, 31-34

Marver, H. S., Tschudy, D. P., Perlroth, M. G., Collins, A. \& Hunter, G. (1966) Anal. Biochem. 14, 53-60

Mauzerall, D. \& Granick, S. (1956) J. Biol. Chem. 219, 435-446

Strand, L. J., Felsher, B. F., Redecker, A. G. \& Marver, H. S. (1970) Proc. Natl. Acad. Sci. U.S.A. 67, 13151320

Wickramasinghe, J. A. F., Morozowich, W., Hamlin, W. E. \& Shaw, S. R. (1973) J. Pharm. Sci. 62, 14281431 